\title{
Stock Market Reactions on Shariah Indices Following Sukuk Issuances: CAAR Analysis on 2008-Financial Crisis
}

Syazwani Abd Rahim, Ahmad Nawawi Yaacob, Munirah Zakaria, Nurfarhana Daud

To Link this Article: http://dx.doi.org/10.6007/IJARBSS/v11-i12/11825

DOI:10.6007/IJARBSS/v11-i12/11825

Received: 16 October 2021, Revised: 21 November 2021, Accepted: 30 November 2021

Published Online: 11 December 2021

In-Text Citation: (Rahim et al., 2021)

To Cite this Article: Rahim, S. A., Yaacob, A. N., Zakaria, M., \& Daud, N. (2021). Stock Market Reactions on Shariah Indices Following Sukuk Issuances: CAAR Analysis on 2008-Financial Crisis. International Journal of Academic Research in Business and Social Sciences, 11(12), 868-872.

Copyright: (c) 2021 The Author(s)

Published by Human Resource Management Academic Research Society (www.hrmars.com)

This article is published under the Creative Commons Attribution (CC BY 4.0) license. Anyone may reproduce, distribute, translate and create derivative works of this article (for both commercial and non0-commercial purposes), subject to full attribution to the original publication and authors. The full terms of this license may be seen

at: http://creativecommons.org/licences/by/4.0/legalcode

Vol. 11, No. 12, 2021, Pg. $868-872$

Full Terms \& Conditions of access and use can be found at http://hrmars.com/index.php/pages/detail/publication-ethics 


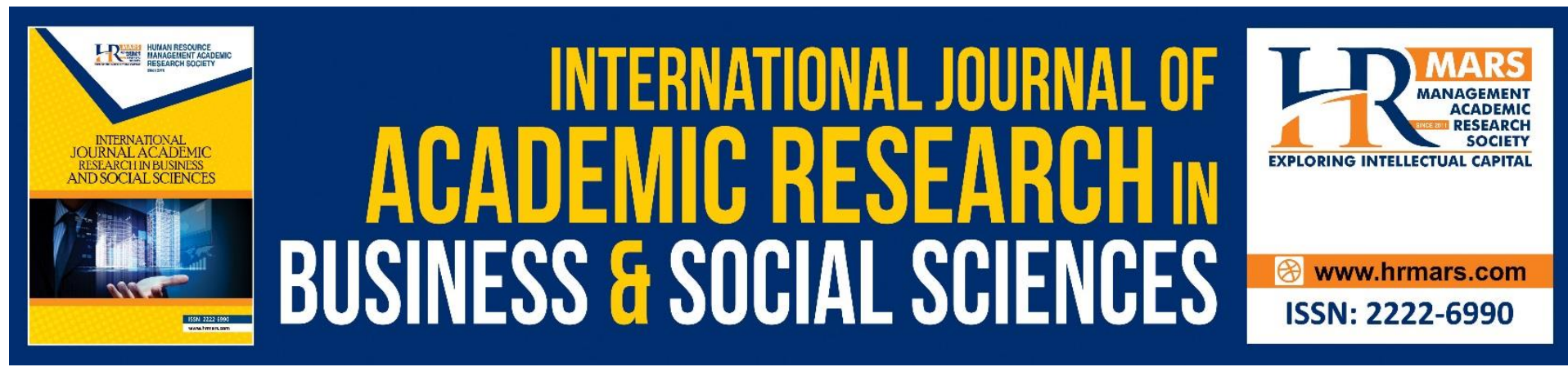

\title{
Stock Market Reactions on Shariah Indices Following Sukuk Issuances: CAAR Analysis on 2008-Financial Crisis
}

\author{
Syazwani Abd Rahim, Ahmad Nawawi Yaacob, Munirah \\ Zakaria, Nurfarhana Daud \\ Academy of Contemporary Islamic Studies (ACIS), Universiti Teknologi MARA, UiTM \\ Cawangan Johor, Kampus Segamat, KM.12, Jalan Muar, 85000 Segamat, Johor, Malaysia \\ Corresponding Author: syazwanirahim@uitm.edu.my
}

\begin{abstract}
The purpose of this study is to look at how stock markets in Malaysia reacted to sukuk issuance announcements from 2004 to the post-2008 financial crisis by examining 50 selected companies listed in The FTSE Bursa Malaysia Kuala Lumpur Composite Index (FBMKLCI), FTSE Bursa Malaysia Emas Shari'ah Index (FBM EMAS), FTSE Bursa Malaysia Hijrah Shari'ah Index (FBM HIJRAH), and Dow Jones Islamic Market Index (DJIM). The data gathered from Datastream, Bloomberg, the Securities Commission Malaysia, and the Bursa Malaysia stock exchange were used to compile this study. A three-year estimation period to investigate market reactions using cumulative average abnormal return (CAAR) was adopted in this study. To investigate market efficiency, this study looked at symmetric and asymmetric event windows. This study discovers that markets responded favourably before the crisis but negatively and significantly during and after the crisis. The findings of this study provide advice to policymakers on how to direct regulators, investors, and issuers to the most stable sukuk during a crisis, as well as useful information and suggestions to issuers, policymakers, regulatory organisations, and investors in Islamic bonds.
\end{abstract}

Keywords: Market Reactions, Sukuk, Shariah Indices, Financial Crisis, CAAR

\section{Introduction}

Since the 2008 financial crisis, the COVID-19 pandemic has posed the greatest challenge to the global financial system (Dali et al., 2021). Though the economic picture will only be clearer once the COVID-19 has been completely eradicated, the first half of 2021 saw the sukuk market to remain resilient (IIFM, 2021). There are many factors that have contributed to the strong growth trend of the sukuk market. First is the favourable expectations for the global economy, relatively stable commodity prices, and the ongoing increase in sovereign sukuk issuance. The strong trend is also caused by the rising interest in sukuk upon the recent issuers of Formosa Sukuk from Taiwan, the sukuk issuing of an Egyptian business in January 2020, and the growing investment base (Ahmad et al., 2021). The recent modernisation of Islamic finance, which has changed the dynamics of the Islamic financial industry, has also resulted in the demand of sukuk to increase in the last few years, resulting in them gaining universal 
acceptance as an alternative to conventional financial products. As a result, recently, sukuk has developed into one of the most effective mechanisms to raise funds from the market using Islamic guidelines. Not only that, but Sukuk also appeals to conventional investors seeking the possibility of increasing an original asset and the value of the sukuk, while the original debt in bonds remained (Mohamed, 2008).

Sukuk is an Arabic word and is the plural of 'sakk', which means "legal instrument, deed, or check". Sukuk is considered as Shari'ah-compliant bonds, where bonds are defined as longterm debt obligations that are secured by a specified asset or a promise to pay (Al-Amine, 2008). Sukuk is defined by Securities Commission Malaysia (2011) as "certificates of equal value which evidence undivided ownership or investment in the assets using Shari'ah principles and concepts approved by the Shari' ah Advisory Council (SAC)". Sukuk differs from conventional bonds because it is governed by the rules of Shari'ah, whereas conventional bonds include the elements of gharar, maysir and riba. Although sukuk and conventional bonds are different, they share some similarities. A conventional bond has a fixed term maturity, bear a coupon (profit) and is tradable with the average yield price. Likewise, sukuk has a fixed term maturity and pays investors a regular return during the maturity period. In addition, sukuk holders have the option to reclaim their capital (Ulusoy \& Ela, 2016). However, sukuk is structured in such a way that their issuance is not an exchange of paper for money consideration with interest as per conventional bonds. Instead, they are based on an exchange of an approved asset for some financial considerations that allow the investors to earn profits from the said transactions (Zin et al., 2011).

According to MENA Sukuk Report (2009), Malaysia was the largest market for sukuk in 2008, raising USD 5.5 billion from 54 issues. During the 2008 financial crisis, the global amount of sukuk issuance decreased sharply by 54.5 per cent to USD15.1 billion compared to USD33.1 billion in 2007. The decline in sukuk issuance was due to the credit crunch that had forced investors to withdraw from the money market, hence exhausting resources for sukuk. The number of global sukuk issuance weakened in the first half of 2008 and remained lower than the 2007 record. Despite the decline, the prospects for sukuk market remained positive due to the existing demand.

Following the 2008 global financial crisis, the stock market reacted negatively to sukuk issuance, resulting in its subsequent decline (Ahmad \& Radzi, 2011). This is supported by the findings of Modirzadehbami and Mansourfar (2011), who found a significant negative abnormal return on the day before the announcement of Islamic bonds between 2005 and 2008 in Malaysia. When the global financial crisis hit the Gulf countries, investors began losing confidence in the market (RAM, 2010). Unfavourable news, such as the global financial crisis, affects trust and confidence among investors in sukuk (Blinder, 2002). Confidence in the economy, and more specifically in the capital market, is an essential catalyst for economic and financial growth. When the level of confidence increases during strong economic conditions, investors desire to buy sukuk. On the other hand, when confidence declines, risktaking by sukuk investors also tends to decline (Dailami \& Masson, 2009). Significant negative returns are associated with negative news. Such events will seriously diminish investors' confidence in the Islamic financial system (Muhamed \& Radzi, 2012). 
Looking at both the increasing expectations of this industry and the growing investor base, the study will investigate the performance of the sukuk industry from pre-, during, and post2008 global financial crisis. By doing so, the main focus of this research is therefore to investigate stock market reactions following sukuk announcements in Malaysia using the event study methodology. This is because sukuk and equity have similar characteristics (Modirzadehbami \& Mansourfar, 2011). Sukuk does not pay interest but generates returns through the commoditisation of capital gain. Therefore, it cannot be classified exclusively as debt because it also shares some stock features.

The structure of the paper is organised as follows. Following the introduction is the section which discusses the background of the study and relevant literature. Section 3 demonstrates the research methodology and research findings. Finally, Section 4 brings the discussion to a close offering some recommendations at the end.

\section{Literature Review \\ Definition of Sukuk}

Sukuk is a prominent element in the Islamic financial system, contributing approximately 90 per cent to the Islamic capital market (Haider \& Azhar, 2010). The Islamic Development Bank (IDB) defines the sukuk as "an asset-backed bond which was designed or structured in accordance with the Shari'ah and which might be traded in the market" (IDB, 2006). The Accounting and Auditing Organization for Islamic Financial Institutions (AAOIFI, 2008), in its Shari'ah Standard 17 (2), defines sukuk as "certificates of equal value representing undivided shares in the ownership of tangible assets, usufructs and services or (in the ownership of) the assets of particular projects or special investment activity".

Meanwhile, the Islamic Financial Services Board (IFSB, 2007), in its Capital Adequacy Standard (IFBS 2), defines sukuk as "certificates that represent the holder's proportionate ownership in an undivided part of an underlying asset where the holder assumes all rights and obligations to such asset". Sukuk is defined by the Securities Commission Malaysia (2011) as "certificates of equal value which evidence undivided ownership or investment in the assets using Shari'ah principles and concepts approved by the Shari'ah Advisory Council (SAC)". Having considered the numerous definitions of sukuk, the present study will employ the definition of sukuk as issued by the Securities Commission Malaysia.

\section{Background of Sukuk}

Sukuk, which is also referred to as an "Islamic bond", is a capital market instrument that enables the owner of the right to obtain income from this asset by considering the right of ownership over an asset and raising funds from the public investors and is among the fastestgrowing instruments in the world (Alpaslan, 2014). It is the most active Islamic debt market instrument in Malaysia because it covers almost 90 per cent of the local Islamic capital market (Haider, 2010). Sukuk was first issued in Malaysia in 1990 by Shell MDS Private Limited, a foreign-owned non-Islamic company. Since the world's first ringgit sukuk was issued, a various form of sukuk have been issued, such as sukuk mudharabah in 1994, sukuk ijarah in 2001, sovereign sukuk in 2002, sukuk musyarakah in 2005 and exchangeable sukuk in 2006 (Said, 2011). 


\section{Sukuk during 2008-Financial Crisis}

The 2008 global financial crisis had an effect on the sukuk market. The global sukuk issuance had declined by more than 50 per cent by the end of 2008, and Malaysia had been hit the hardest, followed by the Gulf Cooperation Council (GCC) countries (Ahmad \& Radzi, 2011). The year 2008 and 2009 were difficult years for the Islamic capital markets, including some high-profile international sukuk defaults (Nanaeva, 2010). In October 2008, the East Cameron Gas Sukuk, worth USD167 million, filed for bankruptcy. Later in May 2009, Dar Al Kuwait failed to meet its obligation on a USD100 million sukuk. Saudi Arabia's Saad Group is another example of an organisation that had failed to meet sukuk payments.

The deterioration of sukuk issuance in Malaysia, especially after the 2008 global financial crisis, has created a complicated situation among sukuk issuers (Ahmad \& Radzi, 2011). Ahmad and Radzi (2011) also said that the reactions of the stock markets in Malaysia were never consistent, and the prices were unpredictable during the crisis. Since the decreased number of sukuk issuances in Malaysia during the 2008 financial crisis, the prices of stock markets also fluctuated, displaying either positive or negative reactions. Negative reactions, as reflected by low stock market index values, indicate a lack of confidence among sukuk investors to invest in sukuk.

Therefore, the growth rate of sukuk issuance also deteriorated during the financial crisis. Based on the previous literature, it is found that the growth rate of sukuk issuance had decreased after the 2008 financial crisis from 1.89 per cent in 2007 to -0.64 per cent in 2008. However, the growth rate for conventional bonds increased from 0.11 per cent in 2007 to 1.58 per cent after the crisis in 2008 . This suggests that the crisis has a higher impact on sukuk than on conventional bonds. The situation raises several questions. First, why did Malaysia experience the hardest hit in terms of sukuk issuance during the financial crisis? Second, why was the growth rate of sukuk issuance at a lower rate than that of conventional bonds?

The deterioration of sukuk issuance and its impact on confidence level among sukuk investors during the crisis are the important issues investigated in this research. Since empirical work on sukuk with respect to stock market reactions and confidence effects are relatively scarce, this research contributes to the literature by providing new information to address the gap. The findings would be significant to regulators, policymakers, industry players, issuers, investors and researchers in the industry.

\section{Overview of Sukuk Development}

A look at the 2021 sukuk issuance pipeline as well as the current issuances suggest a good year for the sukuk market. Sukuk has continued to attract new issuers, with a greater emphasis on ESG-related issuances, an increase in issuances by relatively new entrants such as Nigeria and Egypt, and an expanding investor base, all of which are positively contributing to the market's development. Sukuk is now widely accepted as a viable source of financing for project financing, general-purpose corporate needs, capital adequacy, sovereign budgetary and fiscal requirements, liquidity management, and other purposes (IIFM, 2020).

Global Sukuk issuance increased from around $19.84 \%$ p.a. or USD145.702 billion in 2019 to USD 174.641 billion in 2020. The steady issuance volume during 2020 was mainly due to sovereign sukuk issuances from Asia, GCC, Africa and certain other jurisdictions. Malaysia 
continued to dominate the sukuk market even though the share of countries like Indonesia, UAE, Saudi Arabia and Turkey increased with good volume.

Figure 1: Global Fls Sukuk Issuances (Jan 2001 - Dec 2020)

All Tenor, All Currencies, in USD Millions

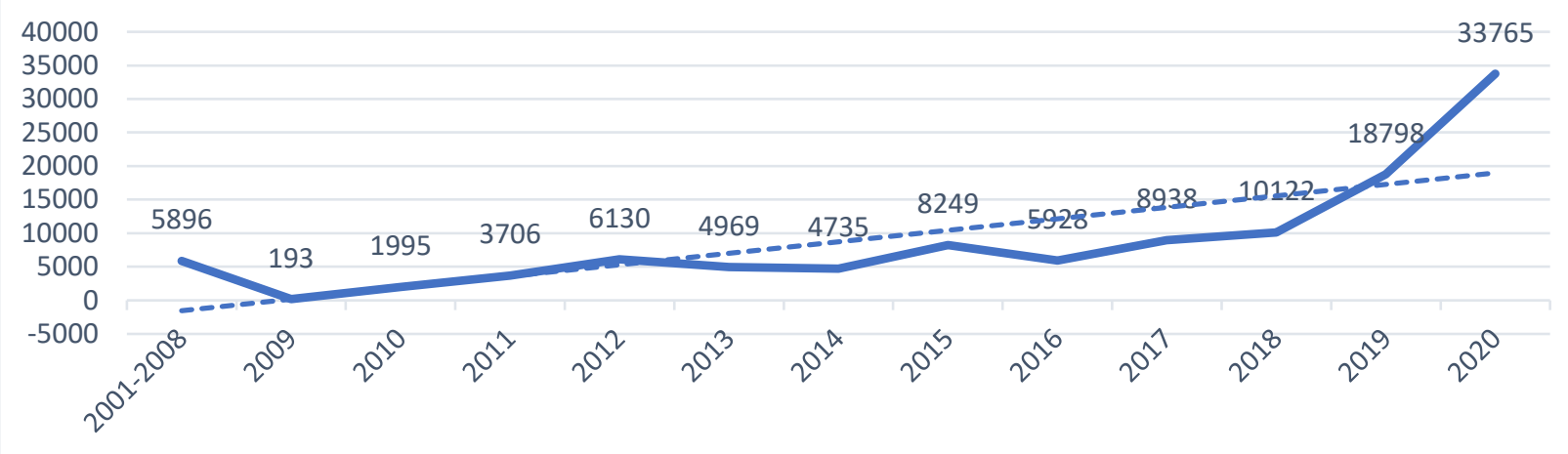

Source: IIFM (2021)

In 2020, sukuk issuances by financial institutions (FIs) showed strong performance, with the issuance volume recorded a new high till the date of USD 33.76 billion, a whopping issuance increase of USD 15.00 billion or $80 \%$ p.a. as compared to the previous year. The Fls were active sukuk issuers since their inception, and initially, the issuances were on the floating profit rate basis, which suited their balance sheet management. Starting from 2010, Fls became more active as an issuer for not only liquidity management purposes but also to meet the Basel Capital Adequacy requirements by issuing Tier 1 (Perpetual) and Tier 2 sukuk. During the year, several Fls based in various jurisdictions have mostly issued Tier 1 Sukuk (IIFM, 2021). The international sukuk market, though it accounts for approximately $24 \%$ of overall Global Sukuk issuances since inception, is the natural attraction and driver of the sukuk market from a global perspective. According to Table 1, the UAE maintained its volume and value leader position in the international sukuk market with a share of $27.01 \%$, closely followed by Malaysia with a share of $25.77 \%$, Saudi Arabia with a share of $19.67 \%$, Indonesia with a share of $6.38 \%$, Bahrain with a share of $4.69 \%$ and with a share of Turkey $5.09 \%$. Together with Saudi Arabia, Qatar, UAE, Oman \& Bahrain, the five GCC countries commanded over $59.07 \%$ of the entire international sukuk issuances since inception. 
Table 1: Regional Break-up of International Sukuk issuance (Jan 2001 - Dec 2020)

\begin{tabular}{|l|r|r|r|}
\hline \multicolumn{1}{|c|}{ ASIA \& FAR EAST } & Number of Issues & $\begin{array}{r}\text { Amount USD } \\
\text { Millions }\end{array}$ & \% of Total Value \\
\hline China & 1 & 97 & $0.03 \%$ \\
\hline Hong Kong & 5 & 3,196 & $0.96 \%$ \\
\hline Indonesia & 24 & 21,203 & $6.38 \%$ \\
\hline Japan & 3 & 190 & $0.06 \%$ \\
\hline Malaysia & 174 & 85,633 & $25.77 \%$ \\
\hline Pakistan & 4 & 3,600 & $1.08 \%$ \\
\hline Singapore & 4 & 711 & $0.21 \%$ \\
\hline Total & $\mathbf{2 1 5}$ & $\mathbf{1 1 4 , 6 3 0}$ & $\mathbf{3 4 . 4 9 \%}$ \\
\hline GCC MIDDLE EAST & Number of Issues & Amount USD & \% of Total Value \\
& 109 & 15,589 & $4.69 \%$ \\
\hline Bahrain & 21 & 5,177 & $1.56 \%$ \\
\hline Kuwait & 5 & 4,219 & $1.27 \%$ \\
\hline Oman & 25 & 16,195 & $4.87 \%$ \\
\hline Qatar & 78 & 65,353 & $19.67 \%$ \\
\hline Saudi Arabia & 138 & 89,764 & $27.01 \%$ \\
\hline United & & & $\mathbf{1 9}$ \\
Emirates & $\mathbf{3 7 6}$ & $\mathbf{1 9 6 , 2 9 7}$ & \\
\hline Total & & & \\
\hline
\end{tabular}

Source: IIFM Sukuk Report (2021)

According to Table 2, around $57.62 \%$ of the international issuance in 2020 came from 5 out of 6 GCC countries. Malaysia was the most active region in International Sukuk issuances with a share of $29.36 \%$, followed by Turkey of $7.01 \%$ and Indonesia of $5.90 \%$ market share.

Table 2: Regional Break-up of International Issuances for the Year 2020

\begin{tabular}{|l|r|r|r|}
\hline AFRICA & Number of Issues & $\begin{array}{r}\text { Amount USD } \\
\text { Millions }\end{array}$ & \% of Total Value \\
\hline Nigeria & 1 & 150 & $0.05 \%$ \\
\hline South Africa & 1 & 500 & $0.15 \%$ \\
\hline Sudan & 1 & 130 & $0.04 \%$ \\
\hline Total & $\mathbf{3}$ & $\mathbf{7 8 0}$ & $\mathbf{0 . 2 3 \%}$ \\
\hline Europe \& OTHERS & Number of Issues & Amount USD & \% of Total Value \\
& & Millions & \\
\hline France & 1 & 1 & $0.0003 \%$ \\
\hline Germany & 3 & 206 & $0.06 \%$ \\
\hline Luxembourg & 3 & 280 & $0.08 \%$ \\
\hline Turkey & 33 & 16,917 & $5.09 \%$ \\
\hline United Kingdom & 11 & 1.769 & $0.53 \%$ \\
\hline USA & 5 & 1,367 & $0.41 \%$ \\
\hline Kazakhstan & 1 & $\mathbf{7 7}$ & $0.02 \%$ \\
\hline Total & $\mathbf{5 7}$ & $\mathbf{2 0 , 6 1 7}$ & $\mathbf{6 . 2 0 \%}$ \\
\hline Grand Total & $\mathbf{6 5 1}$ & $\mathbf{3 3 2 , 3 2 5}$ & $\mathbf{1 0 0 \%}$ \\
\hline
\end{tabular}




\section{Previous Studies on Stock Markets Reactions}

Many studies have been conducted to examine how market participants react to bond announcements and how they affect firm value. A substantial amount of literature has focused on the group of bonds that have both equity and bond components. A noteworthy first finding was by Mikkelson and Partch (1986), who recorded the absence of any significant reaction of the stock markets to conventional bond announcements. This was evident that stock markets do not react to debt announcements, including bond issuances, even if some studies also found evidence for a negative reaction as the reaction of stock markets to the issue of bonds was affected by opposing influences (Spiess \& Affleck-Graves, 1999).

Brown and Warner (1980) said that event studies are frequently used to test market efficiency. An event study is a statistical method used to gauge the impact of a corporate event, such as stock splits, earnings announcements and acquisition announcements. Several studies for the United States market document a significantly negative (on average -1.5 per cent) market response to convertible bond issues, confirming the hybrid nature of these financial instruments. The announcement effect of different corporate securities has been the subject of numerous studies, such as Mikkelson and Partch (1986) for equity, Eckbo (1986) for bonds, and Dann and Mikkelson (1984) for convertible securities. These support the models proposed by (Myers and Majluf, 1984).

However, the results of the effect of issuance analysed in several studies present a mixed picture. For example, Dann and Mikkelson (1984); Mikkelson and Partch (1986); Billingsley et al (1990) found significantly negative stock market reactions on the issuance date for the United States domestic market. However, Kang and Stulz (1996) discovered a significantly positive market reaction in the Japanese market. In general, the stock market does not appear to react very strongly on the date of issue.

Miller and Rock (1985) showed that a larger than expected external financing reveals a lowerthan-expected operating cash flow, which is negative news to investors. This implied a negative stock price effect of an unanticipated debt issue as well as a negative correlation between the price effect and the amount of unanticipated new financing. Thus, the difference between the market's reactions to straight debt and equity issues was broadly consistent with the Myers and Majluf (1984) model. In their framework, the market reacted negatively to unanticipated external financing as relatively uninformed investors account for the possibility that the firm was attempting to take advantage of a situation in which it knows the security offered was priced above its "intrinsic" value. Eckbo (1986) found significantly negative average abnormal returns to firms offering convertible debt. However, straight debt offering, with the exception of a subsample of public utility offerings, was on average associated with zero abnormal performance.

Shaheen (2006) recorded that preliminary evidence showed that acquiring firms did not experience significant abnormal returns around the announcement date. Market participants received no signal on the acquisition announcement day regarding the acquiring firm. Cakir and Raei (2007), who examined the risk-reduction advantage of issuing sovereign sukuk found that adding sukuk to the portfolio of fixed-income securities reduced the VaR, demonstrating that these investment certificates created diversification benefits to investors. 
They suggested that there was no significant market reaction to conventional bond issues but a significant negative stock market reaction to sukuk issues.

Between 2000 to 2006, Ibrahim and Minai (2009) found that the market reaction was significantly positive during event windows $[-3,0]$ and $[-3,3]$ during the announcements of Islamic debt issuance in Malaysia. The wealth effect of Islamic bond issuance announcements was positively influenced by the issuer's investment opportunity and negatively influenced by the size of the issue, the size of the firm and whether the announcement was accompanied by the Securities Commission (SC) approval. The finding implies that the positive reaction was not due to investors' preference for Islamic compliant activities, but it was due to similar factors found in studies on conventional bonds. The negative influence of SC approval on the wealth effect indicates that many listed companies issuing Islamic debt were not complying with the information disclosure requirement.

Ashhari et al (2009) found that there was a wealth effect on the announcement of Islamic bonds issued for the period 2001 to 2006 in Malaysia. The early market reaction to Islamic bond announcements was positive. Regardless of the reactions, a possible reason for the early response could be the fact that information about Islamic bond offerings often leaks out to the market before the announcement. Ameer and Othman (2010) found significant negative abnormal returns near the announcement days in Malaysia over the period of 2001 to 2007. They found that the average abnormal return of the subordinated bonds was significantly positive compared to other types of bonds. The average abnormal return (AAR) for the subordinated bonds was significantly positive and larger than AAR for the medium term and straight bonds, whereas zero-coupon bonds had the most significant negative returns. Since there was no risk of expropriation from the current bondholders, the stock market would react positively to such announcements.

According to Abdul Qoyum (2011), there was a significant positive market reaction just prior to a firms' positive surprise earnings announcements. When a firm announced positive surprise earnings, investors appeared to perceive a positive signal about the firm's future which resulted in an increase in the firm's stock price. Therefore, positive surprise earnings announcements did indeed send a positive signal about the profitability and future success of a firm. By doing so, stock prices rose, and the market reacted quickly to the available information.

On the other hand, according to Modirzadehbami and Mansourfar (2011), a significant negative abnormal return occurred one day before the announcement date in a sample of 45 listed companies on Bursa Malaysia involved in the issuing of Islamic debts during 2005 to 2008. The event window was -15 to +15 days around the announcement date ( 22 working days). The negative abnormal return of the day before the announcement was highly significant at the $5 \%$ level and insignificant on day +1 . Significant negative abnormal return of the day before indicated that the announcement of Islamic bonds in the market reflected bad news in the Malaysian market between the years 2005 to 2008.

\section{The Impact of Financial Crisis and Stock Market Reactions}

Stock markets in Malaysia are flexible and can seriously hamper the Malaysian economy if confidence falls as it did during the 2008 crisis. Historical data show that the FTSE Bursa Malaysia index fell in the months of January to March 2008, May to October 2008 and March 
2009. The index then grew strongly over the period from May to July 2009. Financial crises have had a negative impact on the economy, especially in the sectors that rely on external sources of finance with long-standing financial systems in countries (Mahani \& Rajah, 2009).

According to the MENA Sukuk Report (2009), the sukuk market remained positive because of the existing and strong demand for sukuk. It had also been supported by the higher level of surplus savings and reserves in Asia. The recovery of the sukuk market depended largely on the global financial industry rehabilitation process. This recent crisis in the financial industry led to calls to rely more on Islamic principles as Islamic financial institutions were impacted less than conventional institutions during the crisis. The restrictions placed by Islamic laws on financial transactions had a cushioned impact on Islamic institutions.

According to Asshari et al (2009), news of the Malaysian economy entering a recession following a second-quarter of gross domestic product (GDP) did not profoundly weaken the stock market. This investigation could provide additional insights and further evidence on the effects of debt announcements on stock returns in the emerging capital market in Malaysia. The evidence obtained was useful to international investors who wished to invest and can help to reduce investment risk. Standard and Poor's (2009) reported that the market's anticipated growth of sukuk, including those for infrastructure and project finance, failed to materialise in 2008, with total sukuk issuance falling 56 per cent compared to the previous year. Sukuk fund structures provided an alternative to traditional bank financing that showed no immediate signs of a return in the financial markets.

The global financial crisis in 2008 had a significant impact on stock market reactions. Therefore, it was hard to predict the sukuk markets. It was critical for sukuk holders and investors in other fixed-income financial products to have access to hedging solutions to counter challenges during the crisis. in line with the growth of financial products in the primary market, more attention must be given to the development of Shari'ah-compliant hedging solutions.

\section{Theoretical Framework}

\section{Efficient Markets Theory}

The efficient markets theory covers how the market price reflects the available information, whether the price adjusts quickly and accurately in response to news. According to Frederic (2001) in his book "The Economics of Money, Banking, and Financial Markets", efficient markets theory is the application of rational expectations to the pricing of securities in financial markets. Current security prices will fully reflect all available information because in an efficient market, all unexploited profit opportunities are eliminated. Efficient markets theory also views expectations of future prices as equal to optimal forecasts that use all currently available information. In other words, the market's expectations of future securities prices are rational, which implies that the expected return on the securities is equal to the optimal forecast of the return. In this theory, current prices in a financial market will be set such that the optimal forecast of a security's return when all available information is used is equal to the security's equilibrium return. Consequently, in an efficient market, a security's price fully reflects all available information. 
Frederic (2001) says that the term 'random walk' describes the movements of a variable whose future changes are unpredictable because the variable is just as likely to fall as it is to rise. An important implication of efficient market theory is that stock prices should approximately follow a random walk, which means that future changes in the stock prices should for all practical purposes, be unpredictable. Market efficiency refers to how quickly and precisely security prices adjust to news. As the random walk theory states that news arrives at random, security price changes, therefore, cannot be forecasted.

\section{Event Studies Theory}

Event studies theory explains how the cumulative average abnormal returns (CAAR) are calculated and how a market responds to either positive or negative news. According to Ana (2002), event studies are an important tool in finance for the valuation of firms and for estimating the changes in firm value resulting from, for example, changes in its capital structure. In general, the value of a firm is difficult to measure. However, if there is an efficient market for the firm's stock, the impact of a decision can be measured by the change in the stock price around the time when the decision becomes public knowledge. Although such events can be studied in many ways, the empirical finance literature has taken a particular approach based on statistical tests of the significance of abnormal stock returns around the event dates. The reaction of a stock price to news, which will also change the security price, cannot be predicted, as shown in Figure 2 .

Figure 2: Reaction of Stock Prices to News

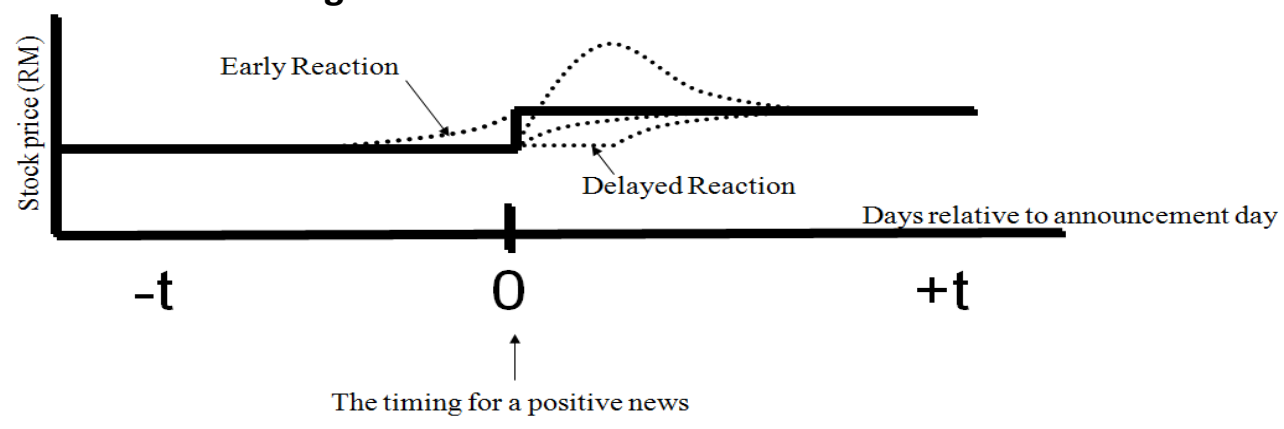

Source: Frederic (2001)

In an event study, it is crucial to test for any evidence of (1) under reaction, (2) overreaction, (3) early reaction, or (4) delayed reaction around the event. If the market is "semi-strongform efficient", the effects of an event will be reflected immediately in the security prices. Thus, a measure of the event's economic impact can be constructed using the security prices that are observed over a relatively short time period (Frederic, 2001).

Fridson (1994), in his book "Advances in Behavioral Finance", mentions that three versions of the Efficient Markets Hypothesis (EMH) can be distinguished depending on the level of available information: (1) weak form EMH, (2) semi-strong form EMH and (3) strong form $\mathrm{EMH}$. The weak form EMH states that current asset prices already reflect past prices and volume information. The information contained in the past sequence of prices of a security is fully reflected in the current market price of that security. It is named weak form EMH because the security prices are the most publicly and easily accessible information. In comparison, the semi strong form EMH states that all publicly available information is already incorporated in the asset prices. All publicly available information is fully reflected in a security's current 
market price. The public information includes not only past prices but also the various data reported in a company's financial statements, company's announcement, economic factors and others. This indicates that the company's financial statements cannot help in forecasting future price movements and in securing high investment returns. Finally, the strong form EMH stipulates that private information or insider information is quickly incorporated in the market prices. Therefore the information cannot be used to generate abnormal trading profits. Thus, all public or private information are fully reflected in a security's current market price. This implies that even the company's management or the insider is neither able to profit nor make gains from the inside information that they have.

According to Frank de Jong (2007), the main differences among the models are the chosen benchmark return model and the estimation interval. An abnormal return (AR) is defined as the return (R) minus a normal return (NR). The determination of the normal return requires the estimation of some parameters. This estimation is typically performed over an estimation period, $\left[\mathrm{T}_{1} ; \mathrm{T}_{2}\right]$, which precedes the event period, $\left[t_{1} ; t_{2}\right]$. The event is typically defined to occur at $\mathrm{t}=0$. The time index $\mathrm{t}$ counts "event time" which is the number of periods (days, months) that have passed from the event does not represent the usual calendar time. Figure 3 shows the time-line of an event study.

Figure 3: Time-Line of an Event Study

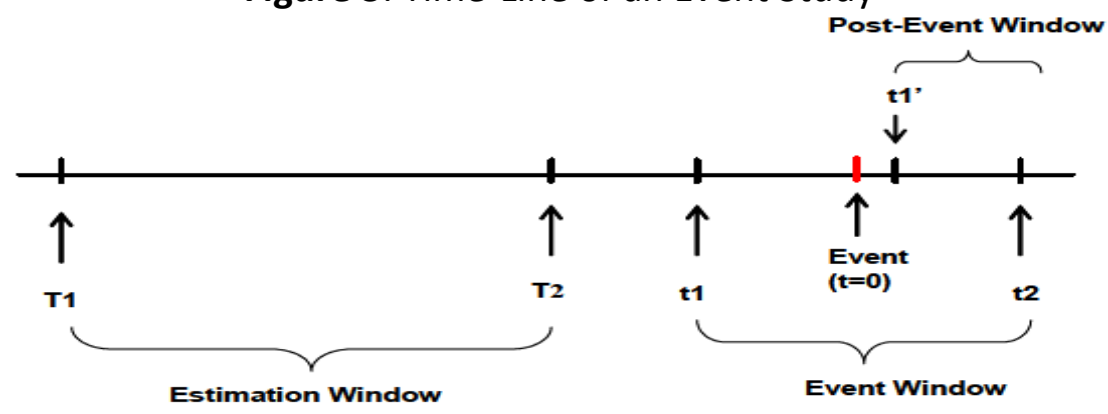

Source: Frank de Jong 2007

Frank de Jong (2007) says that in analysing abnormal returns, it is conventional to label the event date as time $t=0$. Hence, ${ }^{A R_{i ; 0}} A R_{i ; 0}$ denotes the abnormal return on the event date and $\mathrm{AR}_{\mathrm{i} ; \mathrm{t}} \mathrm{AR}_{\mathrm{i} ; \mathrm{t}}$ denotes the abnormal return $\mathrm{t}$ periods after the event. If there is more than one event relating to one firm or stock price series, they are treated as if they affect separate firms. They consider an event period, running from $t_{1} t_{1}$ to $t_{2} \cdot t_{2} \cdot$ In order to study stock price changes around events, each firm's return data can be analysed separately. However, this is not very informative because many stock price movements are caused by information that is unrelated to the event being studied. The effect of this unrelated information could be reduced by averaging the information over several firms, thus improving the accuracy of the study. The average abnormal returns from zero indicate abnormal performance because they are all centred around one event. The average of abnormal returns should reflect the effect of that event. The usual way to study performance over longer intervals is by means of cumulative abnormal returns, where the abnormal returns are aggregated from the start of the event period, $t_{1} t_{1}$, up to time $t_{2} t_{2}$. In event studies, the cumulative abnormal return (CAR) is aggregated over the cross-section of event studies to obtain the cumulative average 
abnormal returns (CAAR). The CAAR estimates can be obtained by aggregating the's over time.

\section{Methodology}

This research employs the event study methodology to analyse the reaction of stock markets to the announcement of a sukuk issuance using the Cumulative Average Abnormal Return (CAAR).

\section{Data Collection}

Sukuk issuance data in Malaysia were obtained from the Bloomberg database, the Securities Commission of Malaysia, Bursa Malaysia, and Zawya Sukuk. The period of the study ran between 2004 and 2011, with three-year estimation windows, because a longer estimation period produces more accurate and robust beta value estimated. The data for stock markets are collected from the historical prices available on the DataStream database, excluding Saturdays and Sundays, giving a total of about 265 days a year.

This research proceeded with the investigation on the stock market reactions to the issuance of sukuk in Malaysia in the FTSE Bursa Malaysia Kuala Lumpur Composite Index (FTSEKLCI), the FTSE Bursa Malaysia Emas Shari'ah Index (FTSE EMAS), the FTSE Bursa Malaysia Hijrah Shari'ah Index (FTSE HIJRAH) and the Dow Jones Islamic Market Index (DJIM). The reactions of different stock markets were compared using the domestic index, the global index, and the Islamic index. For the domestic index, this study used the FTSEKLCl, that covered the period from 2004 to 2011. This study opted the DJIM index for the global Islamic index, and adopted both the FTSE EMAS and the FTSE HIJRAH indices for the local Shari'ah index.

The $\mathrm{KLCl}$ is now known as the FTSE Bursa Malaysia $\mathrm{KLCl}$ after enhancements were implemented on Monday, 6 July 2009. It was enhanced to ensure that $\mathrm{KLCl}$ remains robust in measuring the national economy with growing linkages to the global economy, as well as to provide global relevance, recognition and reach. The FTSE Bursa Malaysia Index was launched on 26 June 2006 followed by the FTSE HIJRAH and the FTSE EMAS on 22 January 2007 and 21 May 2007 respectively. The launch of the FTSE HIJRAH and the FTSE EMAS were in response to the increasing interest in Shari'ah-compliant investments. The FTSE EMAS comprises constituents of the FTSE Bursa Malaysia EMAS index that are Shari'ah-compliant according to the Securities Commission's SAC screening methodology and the FTSE's screens of free float, liquidity and inevitability. The FTSE HIJRAH is a tradable index which comprises the 30 largest companies in the FBM EMAS Index (Bursa Malaysia, 2012).

The following are the introductions to these four indices:

\section{i. FTSE Kuala Lumpur Composite Index (FTSE KLCI)}

Kuala Lumpur Composite Index (KLCl), according to FTSE Group (2012), is a capitalisationweighted stock market index. This index, which includes basic material, health care, technology, consumer goods, consumer service, financial, oil and gas, telecommunications and utility industries, was first introduced in 1986 and is now known as the FTSE Bursa Malaysia KLCl. The FTSE KLCl consists of 100 companies that cover around 81 per cent of the full market capitalisation of the FTSE Bursa Malaysia EMAS Index as of $30^{\text {th }}$ April 2009. In accordance to the $\mathrm{KLCl}$ enhancement, FTSE $\mathrm{KLCl}$ is integrated with the internationally recognised index calculation formula, which increases transparency and makes the index more tradable. 


\section{ii. FTSE Bursa Malaysia Emas Shari'ah Index}

FTSE Group (2012) states that the FTSE Bursa Malaysia Emas Shari'ah Index has been designed to provide investors with a broad benchmark for Shari'ah-compliant investments. This index includes general industries, mobile telecommunications, electricity, food producer, chemical, fixed line telecommunication, and oil and gas industries. Constituents are screened according to the Malaysian Securities Commission's Shari'ah Advisory Council (SAC) screening methodology. The index is designed for the creation of Shari'ah-compliant investment products and as a benchmark. The Shari'ah-compliant companies must not be involved in any financial services based on riba or interest, gambling, manufacture or sale of non-halal products or related products, conventional insurance, entertainment activities that are not permissible according to Shari'ah, manufacture or sale of tobacco-based products or related products, stock broking or share trading in Shari'ah non-compliant securities and other prohibited activities according to Shari'ah.

\section{iii. FTSE Bursa Malaysia Hijrah Shari'ah Index}

FTSE Group (2012) states that the FTSE Bursa Malaysia Hijrah Shari'ah Index has been designed to be used as a basis of Shari'ah-compliant investment products that meet the screening requirements of international Islamic investors. This index includes general industries, mobile telecommunications, electricity, food producers, fixed line telecommunications, oil and gas producers, automobiles and parts, construction and materials, health care, travel and leisure, utilities, and real estate industries. Companies on the index are screened by the Malaysian Securities Commission's Shari'ah Advisory Council (SAC) and a leading global Shari'ah consultancy, Yasaar Ltd, against a clear set of guiding principles. Constituents in the index are not permitted to be involved in any of the following core activities: banking or any other interest-related activities such as lender and brokerages (excluding Islamic financial institutions), alcohol, tobacco, gaming, arms manufacturing, life insurance, pork and non-halal production, packaging and processing, or any other activities related to pork and non-halal food.

\section{iv. Dow Jones Islamic Market Index (DJIM)}

The DJIM was established on 31 December 1995 and serves as an Islamic equity benchmark index. It is a subset of the Dow Jones Global indices (DJGI) family, which includes stocks from 34 countries and covers 10 economic sectors, 18 market sectors, 51 industry groups and 89 subgroups defined by the Dow Jones Global Classification Standard. The DJIM excludes any stock that belongs to a company with a primary business that is impermissible according to Shari'ah law. The purpose of the DJIM is to provide a definitive standard for measuring stock market performance for Islamic investors on a global basis, in accordance with Dow Jones Index's established index methodology and the Islamic investment guidelines established by the index's Shari'ah Supervisory Board. During the component selection process, each company in the index universe is examined based on its revenue allocation. If the company has business activities in any one of the following industry groups or subgroups defined by the Dow Jones Global Classification Standard, it is considered inappropriate for Islamic investment purposes and is excluded from the index. 


\section{Method: CAAR}

\section{Measuring Return $\left(\mathrm{R}_{\mathrm{mt}}\right)$}

In this model, $\mathrm{R}_{\mathrm{mt}}$ is the return on the market portfolio, and the model's linear specification follows from the assumed joint normality of returns. This study defines a return as the difference between the stock market daily price at closing on that day and the stock market daily price at closing on the previous day, divided by the stock market daily price at closing on the previous day. The formula for measuring the return is as follows:

$$
\mathrm{R}_{\mathrm{mt}}=\left[\left(\mathrm{P}_{(\mathrm{t})}-\mathrm{P}_{(\mathrm{t}-1)}\right) / \mathrm{P}_{(\mathrm{t}-1)}\right]
$$

where $\mathrm{P}_{(\mathrm{t})}$ is the stock market daily price at closing. $\mathrm{P}_{(\mathrm{t}-1)}$ is the stock market daily price at closing on the previous day.

This research examined three-day $[-1,+1]$, five-day $[-2,+2]$, seven-day $[-3,+3]$ fifteen-day [$7,+7]$, thirty one-day $[-15,+15]$ and sixty one-day $[-30,+30]$ event windows for symmetric event windows. This study also investigates five-day $[-1,+3]$ and $[-3,+1]$, seven-day $[-2,+4]$ and $[-4,+2]$, nine-day $[-3,+5]$ and $[-5,+3]$, eleven-day $[-3,+7]$ and $[-7,+3]$, fifteen-day $[-4,+10]$ and $[-$ $10,+4]$, thirty one-day $[-10,+20]$ and $[-20,+10]$; and sixty one-day $[-20,+40]$ and $[-40,+20]$ for asymmetric event windows. The average abnormal daily return was calculated and the cumulative average abnormal return (CAAR) is found by summing daily excess returns over the respective event windows. Sixty-one days, 30 days before the announcement day and 30 days after the announcement day, are chosen to facilitate the event window analysis in the emerging market. This time period is chosen because any period shorter than 61 days is insufficient to test the effect of the event, as the volatility of the stock is low. However, in a period of more than 61 days, the effect of the event could not be seen, as there may be other factors that may trigger the effect (Ashhari, et al., 2009).

\section{Daily Return of Stock Market}

The daily return of any stock was calculated using the following formula:

$$
\mathrm{R}_{\text {it }}=\ln \left(\mathrm{P}_{\mathrm{it}} / \mathrm{P}_{\mathrm{i}(\mathrm{t}-1)}\right)
$$

where $R_{i t}$ is the return on security $i$ for day $t . P_{i t}$ is the price of share $i$ for day $t$ and $P_{i(t-1)}$ is the price of share $i$ on the day before day $t$.

\section{Market Model Expected Stock Return}

This research also filtered the sample size to reduce the selected companies to those that had at least 100 days of stock return observation. The following formula was used to calculate the market model's expected stock return:

$$
\mathrm{E}\left(\mathrm{R}_{\mathrm{it}}\right)=\alpha_{\mathrm{i}}+\beta_{\mathrm{i}}\left(\mathrm{R}_{\mathrm{mt}}\right)+\epsilon_{\mathrm{it}}
$$

where $\alpha_{\mathrm{i}}$ is a market model parameter, $\beta_{\mathrm{i}}$ is a market model parameter, $\mathrm{R}_{\mathrm{mt}}$ is the return on market index for day $t, E\left(\mathrm{R}_{\mathrm{it}}\right)$ is the market model's expected stock return and $\epsilon_{i t}$ is the error time.

The parameters for the estimation period were estimated using the ordinary least squares (OLS) method. This study used standard OLS regressions to estimate the market model which represents a potential improvement over the traditional constant-mean-return model because by removing the portion of the return that is related to variation in the market's return, the variance of the AR is reduced. This can increase the ability to detect event effects. To test for the existence of abnormal returns, a benchmark for normal returns is required. Therefore, a parameter estimation period as suggested by Brown and Warner (1985) was used to calculate a stock's $\beta$ value. 
The $\beta$ value is the slope coefficient obtained by regressing the index's returns to the stock's returns, and is also a measure of the stock's volatility compared to the market. The value of $\beta$ needs to be adjusted to avoid biasness. The information on the true value of $\beta$ for a security is important to forecast the future $\beta$, which enables market risk for a future time period to be estimated.

\section{Abnormal Return $\left(\mathbf{A} \mathbf{R}_{\text {it }}\right)$}

To calculate the difference between the actual returns and the expected returns predicted by the market model, the abnormal return $\left(\mathrm{AR}_{\mathrm{it}}\right)$ was obtained from the following formula:

$$
\begin{gathered}
\mathrm{AR}_{\mathrm{it}}=\mathrm{R}_{\mathrm{it}}-\mathrm{E}\left(\mathrm{R}_{\mathrm{it}}\right) \quad \text { or } \\
\mathrm{AR}_{\mathrm{it}}=\mathrm{R}_{\mathrm{it}}-\left[\left(\alpha_{\mathrm{i}}+\beta_{\mathrm{i}} \mathrm{R}_{\mathrm{mt}}\right)+\epsilon_{\mathrm{it}}\right]
\end{gathered}
$$

$\mathrm{R}_{\mathrm{it}}$ is the return on share $i$ in period $t, \mathrm{R}_{\mathrm{mt}}$ is the return on market index during period $t, \mathrm{E}\left(\mathrm{R}_{\mathrm{it}}\right)$ is the market model's expected stock return, $\mathrm{AR}_{\mathrm{it}}$ is abnormal return and $\epsilon_{\mathrm{it}}$ is the error time.

\section{Average Abnormal Return $\left(\mathbf{A A R}_{\mathrm{t}}\right)$}

The average abnormal return $\left(\mathrm{AAR}_{\mathrm{t}}\right)$ is calculated after computing the abnormal returns for all stocks in the sample. In this study, it was calculated by taking the cross-sectional mean of the daily abnormal return:

$$
\mathrm{AAR}_{\mathrm{t}}=\frac{1}{\mathrm{~N}} \sum_{\mathrm{i}=\mathrm{t}}^{\mathrm{N}} \mathrm{AR}_{\mathrm{it}}
$$

$\mathrm{AAR}_{\mathrm{t}}$ is the average abnormal return for day $t, \mathrm{AR}_{\mathrm{it}}$ is the abnormal return of share $i$ for day $t$ and $\mathrm{N}$ is the number of securities in the sample.

\section{Cumulative Average Abnormal Return $\left(\mathrm{CAAR}_{\mathbf{t}}\right.$ )}

After the $\left(\mathrm{AAR}_{t}\right)$ is known, the cumulative average abnormal return $\left(\mathrm{CAAR}_{t}\right)$ is calculated. This research obtained the cumulative average abnormal return (CAAR) by summing the daily excess returns over the respective event windows. CAAR was calculated using the following formula:

$$
\mathrm{CAAR}_{\mathrm{t}}=\sum_{\mathrm{t}-\mathrm{k}}^{\mathrm{t}} \mathrm{AAR}_{\mathrm{t}}
$$

Where $k$ is the number of event days before day $t, \mathrm{CAAR}_{\mathrm{t}}$ is the cumulative average abnormal return and $A_{A} R_{t}$ is the average abnormal return. CAAR needs to be tested for their statistical significance by using t-test. CAAR is important to define whether the Malaysian stock market and the global Islamic index reacted positively or negatively when sukuk was issued after the 2008 financial crisis.

\section{Results and Discussion}

The results of stock market reactions to sukuk issuance in Malaysia for the period under this study on the 50 selected companies are presented in Table 3. The reactions are categorised based on symmetric (six events) and asymmetric (13 events) event windows. The event windows range from 3 to 60 days in length to capture both the immediate and the long term responses, respectively. The analysis for each index is further divided into three distinct 
periods, each representing pre-crisis events (2004 - 2006), the crisis period (2007-2008) and the post-crisis period $(2009-2011)$. Table 4 summarises the findings of Table 3 based on the average values of significant findings to compare the reactions of the different indices.

Table 3: Stock Market Reactions on Different Indexes Following Sukuk Issuance

\begin{tabular}{|c|c|c|c|c|c|c|c|c|c|c|c|c|c|c|}
\hline \multicolumn{15}{|c|}{ MALAYSIAN SUKUK ISSUANCE BY LISTED COMPANIES (2004 - Post 2008 Crisis) } \\
\hline \multirow{3}{*}{ No } & \multirow{3}{*}{$\begin{array}{l}\text { Event } \\
\text { Window }\end{array}$} & \multirow{3}{*}{$\begin{array}{l}\text { Types of } \\
\text { Events }\end{array}$} & \multicolumn{12}{|c|}{ CUMULATIVE AVERAGE ABNORMAL RETURN (CAAR) } \\
\hline & & & \multicolumn{3}{|c|}{ FTSE KLCI INDEX } & \multicolumn{3}{|c|}{ EMAS SHARI'AH INDEX } & \multicolumn{3}{|c|}{ HIJRAH SHARI'AH INDEX } & \multicolumn{3}{|c|}{ DOW JONES ISLAMIC INDEX } \\
\hline & & & $2004-2006$ & $2007-2008$ & Post Crisis & $2004-2006$ & $2007-2008$ & Post Crisis & $2004-2006$ & $2007-2008$ & Post Crisis & $2004-2006$ & $2007-2008$ & Post Crisis \\
\hline 1 & {$[-1,+1]$} & \multirow{6}{*}{$\begin{array}{c}\text { Symmetric } \\
\text { event } \\
\text { windows }\end{array}$} & $\begin{array}{l}0.0018 \\
(.796)\end{array}$ & $\begin{array}{c}-0.0077^{* *} \\
(-2.507)\end{array}$ & $\begin{array}{c}-0.0056^{* *} \\
(-2.145)\end{array}$ & \multirow{20}{*}{$\begin{array}{c}\text { FTSE } \\
\text { Bursa } \\
\text { Malaysia } \\
\text { Emas } \\
\text { Shari'ah } \\
\text { Index } \\
\text { was } \\
\text { launched } \\
\text { on } \\
21 \text { May } \\
2007\end{array}$} & $\begin{array}{c}-0.0100^{* * *} \\
(-3.237)\end{array}$ & $\begin{array}{c}-0.0058^{* *} \\
-2.202\end{array}$ & \multirow{20}{*}{$\begin{array}{c}\text { FTSE Bursa } \\
\text { Malaysia } \\
\text { Hijrah } \\
\text { Shari'ah } \\
\text { Index } \\
\text { was } \\
\text { launched } \\
\text { on } \\
\text { 22 January } \\
2007\end{array}$} & $\begin{array}{c}-0.0096 * * * \\
-3.119\end{array}$ & $\begin{array}{c}-0.0061^{* *} \\
-2.267\end{array}$ & $\begin{array}{c}0.0067^{* *} \\
2.426\end{array}$ & $\begin{array}{c}-0.0110^{* * *} \\
-3.566\end{array}$ & $\begin{array}{c}-0.0057^{* *} \\
-2.145\end{array}$ \\
\hline 2 & {$[-2,+2]$} & & $\begin{array}{l}-0.0006 \\
(-.157)\end{array}$ & $\begin{array}{l}-0.0121^{* *} \\
(-2.090)\end{array}$ & $\begin{array}{l}-0.0077 \\
(-1.594)\end{array}$ & & $\begin{array}{c}-0.0138^{* *} \\
-2.424\end{array}$ & $\begin{array}{l}-0.0079 \\
-1.566\end{array}$ & & $\begin{array}{c}-0.0142^{* *} \\
-2.210\end{array}$ & $\begin{array}{l}-0.0069 \\
-1.396\end{array}$ & $\begin{array}{c}0.0079 \\
1.561\end{array}$ & $\begin{array}{c}-0.0178^{* * *} \\
-2.835\end{array}$ & $\begin{array}{l}-0.0079 \\
-1.594\end{array}$ \\
\hline 3 & {$[-3,+3]$} & & $\begin{array}{l}0.0089^{*} \\
(1.820)\end{array}$ & $\begin{array}{c}-0.0167^{* *} \\
(-2.226)\end{array}$ & $\begin{array}{l}-0.0044 \\
(-.738)\end{array}$ & & $\begin{array}{c}-0.0203^{* * *} \\
-2.726\end{array}$ & $\begin{array}{c}-0.0048 \\
-.764\end{array}$ & & $\begin{array}{c}-0.0241^{* *} \\
-2.617\end{array}$ & $\begin{array}{c}-0.0036 \\
-.589\end{array}$ & $\begin{array}{c}0.0201 * * * \\
3.189\end{array}$ & $\begin{array}{c}-0.0228^{* * *} \\
-2.692\end{array}$ & $\begin{array}{c}-0.0045 \\
-.738\end{array}$ \\
\hline 4 & {$[-7,+7]$} & & $\begin{array}{l}-0.0085 \\
(-.823) \\
\end{array}$ & $\begin{array}{r}-0.0140 \\
(-1.129) \\
\end{array}$ & $\begin{array}{l}-0.0073 \\
(-.847)\end{array}$ & & $\begin{array}{c}-0.0208^{*} \\
-1.671\end{array}$ & $\begin{array}{c}-0.0074 \\
-.819\end{array}$ & & $\begin{array}{c}-0.0318^{* *} \\
-2.562\end{array}$ & $\begin{array}{c}-0.0063 \\
-.722\end{array}$ & $\begin{array}{c}-0.0034 \\
-.289\end{array}$ & $\begin{array}{l}-0.0132 \\
-1.114\end{array}$ & $\begin{array}{c}-0.0075 \\
-.847\end{array}$ \\
\hline 5 & {$[-15,+15]$} & & $\begin{array}{l}-0.0049 \\
(-261)\end{array}$ & $\begin{array}{c}0.1427 * * * \\
(4.388)\end{array}$ & $\begin{array}{c}-0.0254^{* *} \\
(-2.157)\end{array}$ & & $\begin{array}{c}0.1341^{* * *} \\
4.078\end{array}$ & $\begin{array}{c}-0.0279 * * \\
-2.315\end{array}$ & & $\begin{array}{c}0.1163^{* * *} \\
3.445\end{array}$ & $\begin{array}{c}-0.0274^{* *} \\
-2.317\end{array}$ & $\begin{array}{c}0.0058 \\
.277\end{array}$ & $\begin{array}{c}0.1359 * * * \\
4.398\end{array}$ & $\begin{array}{c}-0.0259 * * \\
-2.157\end{array}$ \\
\hline 6 & {$[-30,+30]$} & & $\begin{array}{l}-0.0056 \\
(-161) \\
\end{array}$ & $\begin{array}{c}0.1049 * * * \\
(2.753) \\
\end{array}$ & $\begin{array}{l}-0.0586^{* *} \\
(-2.608)\end{array}$ & & $\begin{array}{c}0.0978^{* *} \\
2.480 \\
\end{array}$ & $\begin{array}{c}-0.0615^{* * *} \\
-2.681 \\
\end{array}$ & & $\begin{array}{c}0.0790^{* *} \\
2.000 \\
\end{array}$ & $\begin{array}{c}-0.0621 * * * \\
-2.711 \\
\end{array}$ & $\begin{array}{c}0.0097 \\
.269 \\
\end{array}$ & $\begin{array}{c}0.0843^{* *} \\
2.323 \\
\end{array}$ & $\begin{array}{c}-0.0597 * * \\
-2.608 \\
\end{array}$ \\
\hline 7 & {$[-1,+3]$} & \multirow{14}{*}{$\begin{array}{c}\text { Asymmetric } \\
\text { event } \\
\text { windows }\end{array}$} & $\begin{array}{c}0.0110^{* *} \\
(2.619) \\
\end{array}$ & $\begin{array}{l}-0.0068 \\
(-1.145) \\
\end{array}$ & $\begin{array}{l}-0.0064 \\
(-1.232) \\
\end{array}$ & & $\begin{array}{c}-0.0107^{*} \\
-1.837 \\
\end{array}$ & $\begin{array}{l}-0.0070 \\
-1.276 \\
\end{array}$ & & $\begin{array}{c}-0.0147^{* *} \\
-2.077 \\
\end{array}$ & $\begin{array}{l}-0.0069 \\
-1.280 \\
\end{array}$ & $\begin{array}{c}0.0209 * * * \\
4.160\end{array}$ & $\begin{array}{l}-0.0085 \\
-1.334 \\
\end{array}$ & $\begin{array}{l}-0.0065 \\
-1.232 \\
\end{array}$ \\
\hline 8 & {$[-3,+1]$} & & $\begin{array}{l}-0.0003 \\
(-.087) \\
\end{array}$ & $\begin{array}{c}-0.0177^{* * *} \\
(-4.234) \\
\end{array}$ & $\begin{array}{r}-0.0036 \\
(-1.013) \\
\end{array}$ & & $\begin{array}{c}-0.0196^{* * *} \\
-4.601 \\
\end{array}$ & $\begin{array}{l}-0.0036 \\
-1.010 \\
\end{array}$ & & $\begin{array}{c}-0.0190^{* * *} \\
-3.887\end{array}$ & $\begin{array}{c}-0.0028 \\
-.769\end{array}$ & $\begin{array}{c}-0.0127^{* * *} \\
-2.999\end{array}$ & $\begin{array}{c}-0.0162^{* *} \\
-2.639\end{array}$ & $\begin{array}{l}-0.0037 \\
-1.013 \\
\end{array}$ \\
\hline 9 & {$[-2,+4]$} & & $\begin{array}{l}-0.0029 \\
(-.470) \\
\end{array}$ & $\begin{array}{l}-0.0158^{* *} \\
(-2.390) \\
\end{array}$ & $\begin{array}{l}-0.0071 \\
(-1.296) \\
\end{array}$ & & $\begin{array}{c}-0.0200^{* * *} \\
-3.080 \\
\end{array}$ & $\begin{array}{l}-0.0075 \\
-1.312 \\
\end{array}$ & & $\begin{array}{c}-0.0255^{* * *} \\
-3.401 \\
\end{array}$ & $\begin{array}{l}-0.0068 \\
-1.200 \\
\end{array}$ & $\begin{array}{c}0.0013 \\
.188 \\
\end{array}$ & $\begin{array}{c}-0.0187^{* *} \\
-2.591 \\
\end{array}$ & $\begin{array}{l}-0.0072 \\
-1.296 \\
\end{array}$ \\
\hline 10 & {$[-4,+2]$} & & $\begin{array}{l}-0.0019 \\
(-.473)\end{array}$ & $\begin{array}{l}-0.0142^{* *} \\
(-2.236)\end{array}$ & $\begin{array}{l}-0.0076 \\
(-1.365)\end{array}$ & & $\begin{array}{c}-0.0172^{* * *} \\
-2.759 \\
\end{array}$ & $\begin{array}{l}-0.0074 \\
-1.279 \\
\end{array}$ & & $\begin{array}{c}-0.0180^{* *} \\
-2.572 \\
\end{array}$ & $\begin{array}{l}-0.0066 \\
-1.160 \\
\end{array}$ & $\begin{array}{c}0.0159^{* *} \\
2.614\end{array}$ & $\begin{array}{c}-0.0228 * * * \\
-3.394\end{array}$ & $\begin{array}{l}-0.0077 \\
-1.365 \\
\end{array}$ \\
\hline 11 & {$[-3,+5]$} & & $\begin{array}{l}-0.0007 \\
(-.085) \\
\end{array}$ & $\begin{array}{l}-0.0184^{* *} \\
(-2.539)\end{array}$ & $\begin{array}{l}-0.0077 \\
(-1.224) \\
\end{array}$ & & $\begin{array}{c}-0.0239 * * * \\
-3.292 \\
\end{array}$ & $\begin{array}{l}-0.0079 \\
-1.218 \\
\end{array}$ & & $\begin{array}{c}-0.0284^{* * *} \\
-3.442 \\
\end{array}$ & $\begin{array}{l}-0.0062 \\
-.977 \\
\end{array}$ & $\begin{array}{c}0.0098 \\
1.142 \\
\end{array}$ & $\begin{array}{c}-0.0267^{* * *} \\
-3.509 \\
\end{array}$ & $\begin{array}{l}-0.0078 \\
-1.224 \\
\end{array}$ \\
\hline 12 & {$[-5,+3]$} & & $\begin{array}{l}0.0055 \\
(.865)\end{array}$ & $\begin{array}{l}-0.0360^{* *} \\
(-2.612)\end{array}$ & $\begin{array}{l}-0.0048 \\
(-.764) \\
\end{array}$ & & $\begin{array}{c}-0.0406^{* * *} \\
-2.942 \\
\end{array}$ & $\begin{array}{l}-0.0050 \\
-.756\end{array}$ & & $\begin{array}{c}-0.0461 * * * \\
-3.061 \\
\end{array}$ & $\begin{array}{c}-0.0044 \\
-.673 \\
\end{array}$ & $\begin{array}{c}0.0165^{* *} \\
2.035\end{array}$ & $\begin{array}{c}-0.0374^{* *} \\
-2.551\end{array}$ & $\begin{array}{c}-0.0049 \\
-.764 \\
\end{array}$ \\
\hline 13 & {$[-3,+7]$} & & $\begin{array}{r}-0.0028 \\
(-356) \\
\end{array}$ & $\begin{array}{r}-0.0108 \\
(-1.403)\end{array}$ & $\begin{array}{l}-0.0069 \\
(-.911) \\
\end{array}$ & & $\begin{array}{c}-0.0168^{* *} \\
-2.202 \\
\end{array}$ & $\begin{array}{c}-0.0070 \\
-.896 \\
\end{array}$ & & $\begin{array}{c}-0.0231 * * * \\
-2.873 \\
\end{array}$ & $\begin{array}{l}-0.0056 \\
-.728 \\
\end{array}$ & $\begin{array}{c}0.0042 \\
.507\end{array}$ & $\begin{array}{c}-0.0154^{* *} \\
-2.032\end{array}$ & $\begin{array}{c}-0.0071 \\
-.911 \\
\end{array}$ \\
\hline 14 & {$[-7,+3]$} & & $\begin{array}{l}0.0032 \\
(.412) \\
\end{array}$ & $\begin{array}{l}-0.0199 \\
(-1.581) \\
\end{array}$ & $\begin{array}{l}-0.0048 \\
(-.697) \\
\end{array}$ & & $\begin{array}{l}-0.0242^{*} \\
-1.915 \\
\end{array}$ & $\begin{array}{l}-0.0052 \\
-.705 \\
\end{array}$ & & $\begin{array}{c}-0.0328^{* *} \\
-2.441 \\
\end{array}$ & $\begin{array}{c}-0.0044 \\
-.613 \\
\end{array}$ & $\begin{array}{l}0.0126 \\
1.307 \\
\end{array}$ & $\begin{array}{l}-0.0207 \\
-1.594 \\
\end{array}$ & $\begin{array}{c}-0.0049 \\
-.697 \\
\end{array}$ \\
\hline 15 & {$[-4,+10]$} & & $\begin{array}{l}-0.0090 \\
(-.770) \\
\end{array}$ & $\begin{array}{l}-0.0214^{*} \\
(-1.774) \\
\end{array}$ & $\begin{array}{l}-0.0156^{*} \\
(-1.679) \\
\end{array}$ & & $\begin{array}{c}-0.0282^{* *} \\
-2.366 \\
\end{array}$ & $\begin{array}{l}-0.0161^{*} \\
-1.664 \\
\end{array}$ & & $\begin{array}{c}-0.0361 * * * \\
-2.879 \\
\end{array}$ & $\begin{array}{l}-0.0151 \\
-1.600 \\
\end{array}$ & $\begin{array}{c}-0.0027 \\
-.218 \\
\end{array}$ & $\begin{array}{c}-0.0250^{* *} \\
-2.308 \\
\end{array}$ & $\begin{array}{c}-0.0159^{*} \\
-1.679 \\
\end{array}$ \\
\hline 16 & {$[-10,+4]$} & & $\begin{array}{r}-0.0118 \\
(-1.192) \\
\end{array}$ & $\begin{array}{l}-0.0033 \\
(-.281) \\
\end{array}$ & $\begin{array}{l}-0.0080 \\
(-1.121) \\
\end{array}$ & & $\begin{array}{c}-0.0093 \\
-.779 \\
\end{array}$ & $\begin{array}{l}-0.0087 \\
-1.134 \\
\end{array}$ & & $\begin{array}{c}-0.0187 \\
-1.585 \\
\end{array}$ & $\begin{array}{c}-0.0073 \\
-1.007 \\
\end{array}$ & $\begin{array}{c}-0.0070 \\
-.587 \\
\end{array}$ & $\begin{array}{c}-0.0153 \\
-1.341 \\
\end{array}$ & $\begin{array}{c}-0.0081 \\
-1.121 \\
\end{array}$ \\
\hline 17 & {$[-10,+20]$} & & $\begin{array}{l}0.0184 \\
(.894) \\
\end{array}$ & $\begin{array}{c}0.0402^{* *} \\
(2.181) \\
\end{array}$ & $\begin{array}{c}-0.0358^{* * *} \\
(-2.823) \\
\end{array}$ & & $\begin{array}{c}0.0289 \\
1.574 \\
\end{array}$ & $\begin{array}{c}-0.0399 * * * \\
-3.032 \\
\end{array}$ & & $\begin{array}{c}0.0136 \\
.752 \\
\end{array}$ & $\begin{array}{c}-0.0386 * * * \\
-3.020 \\
\end{array}$ & $\begin{array}{c}0.0349 \\
1.559 \\
\end{array}$ & $\begin{array}{c}0.0364^{* *} \\
1.987 \\
\end{array}$ & $\begin{array}{c}-0.0365^{* * *} \\
-2.823 \\
\end{array}$ \\
\hline 18 & {$[-20,+10]$} & & $\begin{array}{l}-0.04999^{* *} \\
(-2.037)\end{array}$ & $\begin{array}{c}0.1038^{* * *} \\
(3.270) \\
\end{array}$ & $\begin{array}{l}-0.0216^{* *} \\
(-1.979)\end{array}$ & & $\begin{array}{c}0.0985^{* * *} \\
3.051 \\
\end{array}$ & $\begin{array}{c}-0.0219^{*} \\
-1.922 \\
\end{array}$ & & $\begin{array}{c}0.0801^{* *} \\
2.441 \\
\end{array}$ & $\begin{array}{l}-0.0211^{*} \\
-1.905 \\
\end{array}$ & $\begin{array}{l}-0.0499^{*} \\
-1.984 \\
\end{array}$ & $\begin{array}{c}0.0998^{* * * *} \\
3.332 \\
\end{array}$ & $\begin{array}{c}-0.0220^{* *} \\
-1.979 \\
\end{array}$ \\
\hline 19 & {$[-20,+40]$} & & $\begin{array}{l}-0.0641 \\
(-1.640) \\
\end{array}$ & $\begin{array}{c}0.0903^{* * *} \\
(2.777) \\
\end{array}$ & $\begin{array}{l}-0.0245 \\
(-1.079) \\
\end{array}$ & & $\begin{array}{c}0.0836^{* *} \\
2.538\end{array}$ & $\begin{array}{l}-0.0290 \\
-1.242 \\
\end{array}$ & & $\begin{array}{c}0.1219^{* * *} \\
3.011 \\
\end{array}$ & $\begin{array}{l}-0.0267 \\
-1.149 \\
\end{array}$ & $\begin{array}{l}-0.0486 \\
-1.249 \\
\end{array}$ & $\begin{array}{c}0.0767^{* *} \\
2.468 \\
\end{array}$ & $\begin{array}{l}-0.0250 \\
-1.079 \\
\end{array}$ \\
\hline 20 & {$[-40,+20]$} & & $\begin{array}{l}0.0022 \\
(.069) \\
\end{array}$ & $\begin{array}{c}0.1737^{* * *} \\
(4.165) \\
\end{array}$ & $\begin{array}{c}-0.0741^{* * *} \\
(-4.576) \\
\end{array}$ & & $\begin{array}{c}0.1597^{* * *} \\
3.740 \\
\end{array}$ & $\begin{array}{c}-0.0770^{* * *} \\
-4.645 \\
\end{array}$ & & $\begin{array}{c}0.1361^{* * *} \\
3.189 \\
\end{array}$ & $\begin{array}{c}-0.0771^{* * *} \\
-4.698 \\
\end{array}$ & $\begin{array}{c}0.0088 \\
.271 \\
\end{array}$ & $\begin{array}{c}0.1588^{* * *} \\
3.978 \\
\end{array}$ & $\begin{array}{c}-0.0756^{* * *} \\
-4.576 \\
\end{array}$ \\
\hline
\end{tabular}

Note: $t$-statistics are in parentheses, ${ }^{*}$ Significant at $10 \%,{ }^{* *}$ Significant at $5 \%,{ }^{* * *}$ Significant at $1 \%$

Source: Author's calculation 
INTERNATIONAL JOURNAL OF ACADEMIC RESEARCH IN BUSINESS AND SOCIAL SCIENCES

Vol. 11, No. 12, 2021, E-ISSN: 2222-6990 @ 2021 HRMARS

Table 4: Summary of Cumulative Average Abnormal Return on Stock Market Reactions

\begin{tabular}{|c|c|c|c|c|c|c|c|c|c|c|c|c|}
\hline \multirow{4}{*}{ Indicators } & \multicolumn{12}{|c|}{ Malaysian Sukuk Issuance by Listed Companies } \\
\hline & \multicolumn{12}{|c|}{ Cumulative Average Abnormal Return (CAAR) } \\
\hline & \multicolumn{3}{|c|}{ FTSE KLCl } & \multicolumn{3}{|c|}{ EMAS SHARI'AH } & \multicolumn{3}{|c|}{ HIJRAH SHARI'AH } & \multicolumn{3}{|c|}{ DOW JONES ISLAMIC } \\
\hline & $\begin{array}{l}2004- \\
2006\end{array}$ & $\begin{array}{c}2007- \\
2008 \\
\end{array}$ & $\begin{array}{l}\text { Post } \\
\text { Crisis }\end{array}$ & $\begin{array}{l}2004- \\
2006 \\
\end{array}$ & $\begin{array}{l}2007- \\
2008\end{array}$ & $\begin{array}{l}\text { Post } \\
\text { Crisis }\end{array}$ & $\begin{array}{l}2004- \\
2006 \\
\end{array}$ & $\begin{array}{l}2007- \\
2008\end{array}$ & $\begin{array}{l}\text { Post } \\
\text { Crisis } \\
\end{array}$ & $\begin{array}{l}2004- \\
2006\end{array}$ & $\begin{array}{l}2007- \\
2008 \\
\end{array}$ & $\begin{array}{l}\text { Post } \\
\text { Crisis } \\
\end{array}$ \\
\hline Average Overall & -0.1119 & 0.4407 & -0.3375 & & 0.3272 & -0.3585 & & 0.2050 & -0.3420 & 0.0508 & 0.3207 & -0.3441 \\
\hline Average Significant & -0.0100 & 0.0330 & -0.0337 & & 0.0171 & -0.0357 & & 0.0117 & -0.0387 & 0.0025 & 0.0236 & -0.0345 \\
\hline $\begin{array}{c}\text { Average } \\
\text { Symmetric }\end{array}$ & -0.0015 & 0.0329 & -0.0182 & & 0.0278 & -0.0192 & & 0.0193 & -0.0188 & 0.0078 & 0.0259 & -0.0185 \\
\hline $\begin{array}{c}\text { Average } \\
\text { Asymmetric }\end{array}$ & -0.0074 & 0.0174 & -0.0163 & & 0.0114 & -0.0174 & & 0.0064 & -0.0164 & 0.0003 & 0.0118 & -0.0166 \\
\hline Minimum & -0.0641 & -0.0360 & -0.0741 & & -0.0406 & -0.0770 & & -0.0461 & -0.0771 & -0.0499 & -0.0374 & -0.0756 \\
\hline Maximum & 0.0184 & 0.1737 & -0.0036 & & 0.1597 & -0.0036 & & 0.1361 & -0.0028 & 0.0349 & 0.1588 & -0.0037 \\
\hline $\begin{array}{c}\text { No of Significant } \\
(+v e)\end{array}$ & 2 & 6 & 0 & & 5 & 0 & & 5 & 0 & 5 & 6 & 0 \\
\hline $\begin{array}{l}\text { No of Significant (- } \\
\text { ve) }\end{array}$ & 1 & 9 & 7 & & 13 & 7 & & 13 & 6 & 2 & 10 & 7 \\
\hline
\end{tabular}

Note: The average values are calculated based on the significant findings from Table $4 . n=50$ companies.

Source: Author's calculation 
Table 3 shows 20 event windows separated by symmetric and asymmetric events. The minimum event was 3 days $[-1,+1]$ and the maximum event was 61 days: $[-30,+30],[-20,+40]$ and $[-40,+20]$. The announcement day (day 0 ) is defined as the day the sukuk offering was first made known to the public. This is supported by Ashhari et al (2009), that mentioned the effects of the events may not be visible for periods of more than 61 days, as other factors may trigger the effects.

In this study, there were six symmetric 3, 5, 7, 15, 31 and 61-day events. A symmetric event is when there is the same number of days before and after the announcement of sukuk issuance. There were 14 asymmetric events from 5 days to a maximum of 61 days. The events were separated in order to study market efficiency in Malaysia. In an efficient market, the closing price of the stock market fully reflects all available information. The stock prices should approximately follow a random walk as future changes in stock prices should be unpredictable.

Table 3 shows that there are similar patterns in the results following the information of sukuk issuances across the four indices. The FTSE KLCI and DJIM indices show they were sharing the same asymmetric event $[-10,+20]$, with a maximum value of CAAR 10 days before and 20 days after the sukuk announcement. The maximum value of CAAR before the crisis on FTSE KLCl was 0.0184 , which was lower than the maximum value of DJIM at 0.0349 , with both showing positive but insignificant results. The positive response to these two indices before the crisis showed the sukuk investors' confidence about investing in sukuk in both local and global markets. Table 4 shows two positive and significant FTSE KLCl results and five positive and significant DJIM results before the crisis. Both indices had a larger number of positive significant results compared to negative significant results before the crisis. Thus, the stock markets reacted positively before the 2008 financial crisis based on the CAAR estimated, is accepted.

During the crisis, the four indices shared the same event for the maximum value of CAAR. All indices showed positive and significant results of $1 \%$ on the asymmetric event $[-40,+20]$. The FTSE KLCl had the highest value among these indices which was at 0.1737. The FBM HIJRAH yielded the lowest result of 0.1361 . These results show that in all four indices, an asymmetric event with more days before the announcement is the most significant. The results also indicate that short events show negative results in both symmetric and asymmetric events. However, long term events, both symmetric and asymmetric events, produce positive and significant results. This means the markets react negatively following negative information, such as during the 2008 global financial crisis.

According to Table 3, all four indices show the same pattern with negative results in short events and positive results in long events during the crisis. Overreaction or delayed reactions occur in longer events which show an inefficient market or weak-form efficiency that do not react to all public information. These overreactions, which presumes that investors overreact to positive and negative shocks and correct their behavior, may suggest that the market took longer to process the crisis information. This is because the previous empirical evidence shows that significant negative returns are associated with negative news. These results support Cahyadin and Milandari (2009) who found that the Dow Jones Islamic Market Index and FBM Emas Shari'ah Index had weak-form efficiency. 
All four indices also share the same event as the minimum value of CAAR which was the asymmetric event $[-5,+3]$. Among the four indices, FBM HIJRAH scored the lowest at -0.0461 with $1 \%$ significance and the highest was FTSE $\mathrm{KLCl}$ with $5 \%$ significance. The asymmetric event $[-5,+3]$ had the worst result of all four indices. These negative and significant results were due to negative information during the crisis. Accordingly, Table 4 also shows that all four indices respond more to negative than positive significant results during the crisis. The FBM EMAS and FBM HIJRAH show the highest number of negative and significant results compared to the other two indices, with 13 such results. Thus, the stock markets reacted negatively and significantly during the 2008 financial crisis based on the CAAR estimated.

The period after the crisis showed that all event windows, both symmetric and asymmetric events, reacted to negative results on all four indices. All events showed no positive results after the crisis. After the crisis, markets showed negative results following negative information. All indices indicated negative and significant results, with no positive and significant results. All indices also shared the same event as the maximum results of CAAR, which was on the asymmetric event $[-3,+1]$. This showed that short events yielded the maximum results after the crisis. Moreover, after the crisis, the same event had a minimum value of CAAR on all the four indices on the asymmetric event $[-40,+20]$. All indices were negative with significant results of $1 \%$ on this event. The lowest value of CAAR after the crisis was on FBM HIJRAH, which was -0.0771 with $1 \%$ significance. This meant the markets took a longer time to process negative news. After the crisis, sukuk investors' confidence was lower than before the crisis happened. These results are acceptable for hypothesis that stock markets responded negatively and significantly following sukuk issuance after the 2008 financial crisis based on the CAAR estimated.

A summary of eight indicators is shown in Table 5. During the crisis, all four indices showed positive results in all indicators except the minimum indicator. Nevertheless, after the crisis, all four indices showed negative results in all indicators, hence sharing the same pattern. However, before the crisis the FTSE KLCl had showed negative results except on the maximum indicator and the DJIM had showed positive results except on the minimum indicator. None of all these four indices showed positive and significant results after the crisis. The results show that asymmetric events reacted better than symmetric events considering all the maximum values of CAAR came from the asymmetric events in all three periods, before, during and after the crisis.

\section{Conclusion}

This research has discovered that stock markets reacted positively before the 2008 financial crisis based on CAAR estimates. They then, based on CAAR estimates, reacted negatively and significantly during and after the global financial crisis. All indices showed the same pattern of results and thus the thesis hypothesis was accepted. The researcher found that the FTSE $\mathrm{KLCl}$ was the best index compared to the other indices. Although the FTSE KLCl combined Islamic and conventional listed companies, this study focused on 50 listed companies that had issued sukuk in Malaysia. As the new Islamic benchmark in Malaysia, the FBM EMAS and the FBM HIJRAH did not cover the early period of study before the crisis happened, hence was not entitled to be the best index. Meanwhile, the DJIM index as the global Islamic index was used to show the effect of the financial crisis on the global market. By doing so, the researcher suggests referring to the reactions of FTSE $\mathrm{KLCl}$ as the indicator index following sukuk 
issuances in Malaysia. Considering that the FTSE KLCl covered all periods of study, it could be used as the main index in Malaysia to investigate market reaction on sukuk issuances.

All indices in this study showed weak-form efficiency. Weak-form efficiency occurs when stock prices reflect all the information found in past stock prices. Stock prices reacted so fast to past information that no investor could earn an above-average risk-adjusted return by acting on this level of information. Thus, the security market was inefficient and that resulted in stock prices to not accurately reflect new information. The researcher finds that this might have resulted from: 1 ) investors were unable to interpret the new information correctly; 2 ) investors had no access to new information; 3 ) the transaction cost in trading security was an obstruction to free trading; 4) investors were affected by short-sale restrictions; and finally, 5 ) investors might have been misled by the change in accounting principles.

The results showed that during the 2008 crisis, the market reacted negatively as it was impacted by negative information. There were overreactions in the market which took a longer time to absorb negative news because of the lack of information among sukuk investors and issuers. Nevertheless, the results showed positive reactions after the crisis, indicating that the overreactions during the crisis had recovered slowly. In conclusion, this analysis provides valuable information and guidelines to issuers, policy makers, regulatory bodies, and investors, both Muslim and non-Muslim, and it has potential to draw them to Islamic bonds.

\section{Acknowledgement}

This research acknowledges the Geran Bestari (G-BEST) Universiti Teknologi MARA Cawangan Johor, G-BEST Fasa 2/2020 that sponsors this publication.

\section{Corresponding Author}

Dr. Syazwani Abd Rahim

Academy of Contemporary Islamic Studies (ACIS), Universiti Teknologi MARA, UiTM Cawangan Johor, Kampus Segamat, KM12, Jalan Muar, 85000 Segamat, Johor, Malaysia Email: syazwanirahim@uitm.edu.my

\section{References}

AAOIFI. (2008). Investment Islamic Bonds (Shari'ah Standard No. 18). Manama: Accounting and Auditing Organization for Islamic Financial Institutions (AAOIFI). $<$ http://www.aaoifi.com>

Abdul-Qoyum \& Ardiansyah, M. (2011). Testing the Semi-Strong Form Efficiency of Islamic Capital Market with Response to Information Content of Dividend Announcement- A Study in Jakarta Islamic Index. International Conference on Management (ICM 2011) Proceeding.

Ahmad, W., \& Radzi, R. M. (2011). Sustainability of Sukuk and Conventional Bond during Financial Crisis: Malaysia's Capital Market. Global Economy and Finance Journal, 4(2).

Ahmad, N., Rahim, S. A., Lee, U. H. M. S., \& Riduan, N. A. S. M. (2021). The Misery Index Revisited: The Case of Sukuk Issuing Countries. E-Proceeding on International Seminar on Islam and Science, 2021.

Al-Amine, M. B. (2008). The Islamic Bonds Market: Possibilities and Challenges. International Journal of Islamic Financial Services, 3(1). 
Alpaslan, H. I. (2014). Sukuk, as a New Financial Instrument (Lease Certificates) and Sukuk Accounting. Financial Research and Studies Journal, 6(11), 15-31. DOI. 10.14784/JFRS.2014117325.

Ameer, R., \& Othman, R. (2010). Stock Market Reaction to Bonds Issuance: Evidence from Malaysian Banking Sector. International Research Journal of Finance and Economics, (45), ISSN 1450-2887.

Ana, P. S. (2002). Event Study Tests: A Brief Survey. Universidade do Porto - Faculdade de Economia (FEP), 2(3).

Ashhari, Z. M., Chun, L. S., \& Nassir, A. M. (2009). Conventional vs Islamic Bond Announcements: the Effects on Shareholders' Wealth. International Journal of Business and Management, 4(6).

Billingsley, R. S., Lamy, R. E., \& Smith, D. M. (1990). Units of Debt with Warrants: Evidence of the Penalty-Free Issuance of an Equity-Like Security. Journal of Financial Research, 8(3).

Brown, S. J., \& Warner, J. B. (1980). Measuring Security Price Performance. Journal of Financial Economics, (8).

Cakir, S., \& Raei, F. (2007). Sukuk vs. Eurobonds: Is There a Difference in Value-at-Risk. International Monetary Fund Working Paper.

Cahyadin, M., \& Milandari, O.D. (2009). Analisis Efficient Market Hypothesis (EMH) di Bursa Saham Syariah, 2005: 1-2008:11. Jurnal Ekonomi Islam, 3(2).

Dali, N. R. S. M., Nawang, W. R. W., Hamid, H. A., Lee, U. H. M. S., \& Nazarie, W. N. F. M. (2021). Financial Vulnerability Among Malaysians Amid Covid19. Keynote Paper. EProceeding on International Seminar on Islam and Science, 2021.

Dann, L., \& Mikkelson, W. (1984). Convertible Debt Issuance, Capital Structure Change and Financing-Related Information: Some New Evidence. Journal of Financial Economics, (13).

Eckbo, B. (1986). Valuation Effects of Corporate Debt Offerings. Journal of Financial Economics. (15).

Fridson. (1994). Advances in behavioral finance. Third Edition. John Wiley \& Sons, Inc.

Haider, J., \& Azhar, M. (2010). Islamic Capital Market: Sukuk and Its Risk Management in the Current Scenario. Umea School of Business \& Economics. Umea University. Sweden.

Ibrahim, Y., \& Minai, M. S. (2009). Islamic Bonds and the Wealth Effects: Evidence from Malaysia. Investment Management and Financial Innovations, 6(1).

Islamic Development Bank. (2006). IDB Annual Report 1426H (2005-2006).

IIFM Sukuk Report. (2021). A Comprehensive Study on Global Sukuk Market. 10th Edition. July 2021. https://www.iifm.net/wp-content/uploads/2021/08/IIFM-Sukuk-Report-10thEdition.pdf

IFSB. (2009). Capital Adequacy Requirements for Sukuk, Securitisations and Real Estate Investment. Islamic Financial Services Board.

Frederic, S. M. (2001). The Economics of Money, Banking, and Financial Markets. Columbia University.

Kang, J. K., \& Stulz, R. M. (1996). How Different Is Japanese Corporate Finance? An Investigation of the Information Content of New Security Issues. Review of Financial Studies, 9(1).

Mikkelson, W., \& Partch, M. (1986). Valuation Effects of Security Offerings and the Issuance Process. Journal of Finance Economics, (15).

Miller \& Rock. (1985). Dividend Policy under Asymmetric Information. Journal of Finance, 40(4). 
Modirzadehbami, S., \& Mansourfar, G. (2011). Information Content of Islamic Private Debt Announcement: Evidence from Malaysia. World Academy of Science, Engineering and Technology.

Myers, S., \& Majluf, N. (1984). Corporate Financing and Investment Decisions When Firms Have Information That Investors Do Not Have. Journal of Financial Economics, (13).

Nanaeva, Z. K. (2010). How Risky Sukuk are: Comparative Analysis of Risks Associated with Sukuk and Conventional Bonds. (Master Thesis). MSc in Finance and Banking. The British University in Dubai.

Said, A. (2011). Does the Use of Sukuk (Islamic bonds) Impact Islamic Banks Performances? A Case Study of Relative Performance during 2007-2009. Middle Eastern Finance and Economics, (12).

Securities Commission Malaysia. (2011). Annual Report of Securities Commission Malaysia 2011.

Shaheen, I. (2006). Stock Market Reaction to Acquisition Announcements using an Event Study Approach. Department of Economics.

Spiess, D., \& Affleck-Grave, J. (1999). The Long-Run Performance of Stock Returns following Debt Offering. Journal of Financial Economics, 1(54).

Ulusoy, A., \& Ela, M. (2017). Lack of Standardization in Sukuk Market. DOI: 10.12816/0051160. 